IJßER

ISSN: 2149-5939

\title{
Yoksunluk yaşayan bireyler sosyal dışlanmaya maruz kalır mı? Türkiye örneğii
}

Do individuals facing with deprivation expose to social exclusion? The case of Turkey

\author{
Sibel Selim ${ }^{1} \quad$ Pınar Çomuk $^{2}$
}

Received Date: 10 / 03 / $2017 \quad$ Accepted Date: 10 / 06 / 2017

\begin{abstract}
$\ddot{\boldsymbol{O}} z$
Sosyal dışlanma kavramı, Avrupa'da doğan ve gelişen bir kavram iken küreselleşmenin de etkisiyle birlikte diğer tüm ülkelerde benimsenen önemli bir sorun halini almıştır. Toplumsal yaşamdan uzaklaşacak düzeyde insanların maddi ve manevi yoksunluk yaşıyor olmaları sosyal dışlanma kavramının ne kadar önemli olduğunu göstermektedir. Bu doğrultuda bu çalışmadaki amaç, 2010-2013 ylllarında Türkiye İstatistik Kurumu'nun gerçekleştirmiş olduğu Gelir ve Yaşam Koşulları (Panel) araştırması verileri kullanılarak toplumsal ve ekonomik yoksunluk yaşayan bireylerin maruz kaldiğ sosyal dışlanma olgusunu etkileyen etmenleri Panel Regresyon Modeli ile analiz etmektir. Bu çalışmadan elde edilen bulgulara göre, toplumsal ve ekonomik yoksunluk yaşayan bireyler aynı zamanda sosyal dışlanmaya maruz kalmaktadır ve bu durum ilerleyen yıllarda da artarak devam etmektedir.
\end{abstract}

Anahtar Kelimeler: Yoksunluk, Sosyal Dışlanma İndeksi, Panel Veri Analizi, Türkiye

\begin{abstract}
The term social exclusion has transformed into an important problem considered in all other countries with the effect of globalization while it was a term which was born and improved in the Europe. Individuals are deprived of material and spiritual opportunities, which this situation cause them to keep away social life, show us how important the term social exclusion. In this direction, the aim of this study is to examine the factors affecting social exclusion case which individuals facing with social and economic deprivation are exposed to using Income and Living Conditions (Panel) Research Data produced by Turkish Statistical Institute in the periods of 2010-2013 with Panel Data Analysis. According to the findings from this study, individuals who exposed to social exclusion faced with social exclusion in the later part of lives of them.
\end{abstract}

Keywords: Deprivation, Social Exclusion Index, Panel Data Analysis, Turkey.

\section{Giriş}

İlk olarak 1960'larda Fransa'da kullanılmaya başlayan bir kavram olan sosyal dışlanma kavramı, 1970'li yıllarda iktisadi kriz ve resesyonun yaşanmasıyla ile birlikte tüm dünya ülkelerinin dikkatini çeken bir kavram haline gelmeye başlamış ve bu dönemde akademisyenler, uygulamacılar, gazeteciler, bürokratlar ve politikacılar; yoksullardan üstü kapalı bir biçimde "dışlanmış (les exclus)" olarak söz etmişlerdir (Evans ve Deluca,2000:1).

Sosyal dışlanma kavramının ilk olarak Fransa'da ortaya çıkmasının en önemli sebeplerinden birisi de Fransa'da sosyalizm ve liberalizasyon tabanlı bireycilik yerine toplumsal bütünleşmeyi esas alan sosyal refah devleti anlayışının benimsenmesidir (De Haan, 1998). Sosyal dışlanma kavramı ile ilgili tanımlara bakıldığında tanımların çeşitliliği ve çokluğu dikkat çekmektedir. Hem bir süreci hem de durumu ifade eden sosyal dışlanma kavramı ülkeden ülkeye göre farklılık

\footnotetext{
* Bu çalışma 27-29 Nisan 2017 tarihinde İtalya-Roma'da gerçekleştirilen 3rd International Conference on Social Science and Education Research (ICSSER) kongresinde bildiri olarak sunulmuştur.

${ }^{1}$ Sorumlu yazar, Prof, Dr., Manisa Celal Bayar Üniversitesi, İktisadi ve İdari Bilimler Fakültesi, Ekonometri Bölümü, sibel.selim@cbu.edu.tr

${ }^{2}$ Öğr. Gör., Manisa Celal Bayar Üniversitesi, Kula Meslek Yüksekokulu, Finans, Bankacılık, Sigortacılık Bölümü, pinar.eryigit@cbu.edu.tr
} 
Selim, S., Çomuk, P., (2017). Yoksunluk yaşayan bireyler sosyal dışlanmaya maruz kalır mı? Türkiye örneği. International Journal of Social Sciences and Education Research, 3 (3), 1041-1053.

gösterebilmektedir. Örneğin; gelişmiş bir ülkedeki ile gelişmekte olan bir ülkede yaşayan bireyler aynı sorunları farklı biçimde yaşayacaklar ve farklı sosyal dışlanmaya maruz kalacaklardır (Çakır, 2002:84). Bu nedenle sosyal dışlanma kavramının genel kabul gören ve ortak görüş birliğine varılan tek bir tanımı bulunmamaktadır. Sosyal dışlanma kavramı ile ilgili tanımlamalar şu şekilde karşımıza çıkmaktadır:

Wagle (2002), sosyal dışlanma kavramını; "insanların yaşadıkları topluma tamamıyla katılımından kısmen ya da bütünüyle dışlanan birey ya da grupları gösteren bir süreç" olarak ifade etmektedir (Wagle, 2002).

Sosyal dışlanma kavramının bir diğer tanımı da, coğrafi olarak bir toplumun üyesi iken toplumdaki vatandaşların gerçekleştirdiği üretim, tüketim, tasarruf gibi ekonomik ya da sosyal ve siyasal eylemlere katılamama durumu şeklindedir (Peace, 2001).

Sosyal dışlanma kavramının tanımıyla ilgili Farrington (2002), yaptığı çalışmasında sosyal dışlanmanın tanımlarını; süreçler, insanlar ve çevre olmak üzere üç grupta toplamıştır.

Çok çeşitli tanımlamaları yapılan sosyal dışlanma kavramı, sadece ekonomik alanda değil toplumsal ve siyasi alanda da kendini göstermektedir. İnsanların hayatlarını olumsuz etkileyerek, yoksunluk çekmelerine neden olan sosyal dışlanma kavramı önemi giderek artan ve sosyal politikalar içerisinde yer almaya başlayan bir kavram haline geldiği görülmektedir. Sosyal dışlanma, yalnızca ekonomik göstergelerle ölçülemeyecek bir durum olmakla birlikte bireylerin yaşı, cinsiyeti, toplumdaki diğer kişilerle olan etkileşimi, fiziksel engelinin olması, yetersiz sosyal korunmaya sahip olması, sosyal destekten mahrum kalmasını da kapsayan bir kavramdır.

Sosyal dışlanma kavramının Türkiye'de gelişimine bakıldığında yaşanılan ekonomik olaylardan etkilendiği söylenebilmektedir. Türkiye'de son yıllarda ortaya çıkan yüksek büyümenin beraberinde getirdiği yeni istihdam olanaklarının yeterli olmadığı ve işsizlik olgusunun giderek artmakta olduğu açıkça görülmektedir. Kısa ve orta vadede işsizliğin azaltılmasına yönelik geniş kapsamlı herhangi bir girişimde bulunulmamakla birlikte bu durum özellikle gençler arasındaki işsizliği giderek arttırmaktadır. Doğal olarak büyük ve önemli çaptaki bu işsizlik sorununun beraberinde sosyal dışlanma kavramının ortaya çıkması kaçınılmaz olmaktadır. 1980'li yıllarda Türkiye ekonomisinin dünya pazarlarına açılımı başlamış ve bu süreç 1990 yılına kadar tamamlanmıştır. Dünya pazarına açılım sürecinde, ilk olarak mal piyasalarında dış piyasaya açılım gerçekleşmiştir. Yüksek bir devalüasyonunun ardından döviz kuru esnekleştirilmiş ve dolaylı teşviklerle birleştirilerek sanayinin ihracata yönlendirilmesi sürecinde temel bir araç olmuştur. Ulusal mali piyasaların dış finans merkezleriyle uyum sağlaması ve liberalleştirilmesi süreci ile Türkiye ekonomisi 1990'lı yıllara tamamıyla dışa açık bir ekonomi, konumunda girmiştir (Yeldan, 2008). 1987-1994 döneminde Körfez Savaşı'nın ardından yaşanan gelişmeler Türkiye ekonomisini olumsuz yönde etkilemiştir. Türkiye bu dönemi, daralan diş ekonomik ilişkilerin etkisi ile yapısal uyum programlarına ve ekonomik istikrarı sağlamaya yönelik yapılan programlara başvurmayı gerektirecek kadar zorlu şartlar altında geçirmiştir. Bu dönemde, yüksek enflasyon oranları ve ekonomik büyümede istikrarsızlık ortaya çıkmıştır. Öte yandan, kırdan kente göç ile artan işsizlik sorunu daha da öne çıkmış ve hızlı kentleşmenin yarattığı rekabet ortamının etkisiyle gelir dağılımı adaletsizliğinin artmış olduğu görülebilmektedir (Dağdemir, 2002). Türkiye'de son y1llarda gözlenen yüksek büyümenin beraberinde yeni istihdam olanaklarının yeterli olmadığı ve işsizliğin giderek artmakta olduğu bir gerçektir. Orta ve az gelişmiş ülkelerde olduğu gibi Türkiye'de de gelir dağılımı oldukça adaletsiz hale getirmiştir. Gelir dağılımındaki bu adaletsizlikler beraberinde yoksulluk sorununu da 
Selim, S., Çomuk, P., (2017). Yoksunluk yaşayan bireyler sosyal dışlanmaya maruz kalır mı? Türkiye örneği. International Journal of Social Sciences and Education Research, 3 (3), 1041-1053.

getirmiştir. Küreselleşme süreci ile birlikte yoksulluk en büyük sıkıntılara yol açan, çözümü konusunda sosyal bilimlerde en çok tartışılan bir konu durumuna gelmiştir. Türkiye'de sosyal dışlanma sorununun da gelir dağılımı adaletsizliği, eşitsizlik ve yoksullukla beraber varlık gösterdiği söylenebilmektedir (Bölükbaşı, 2008).

Bu çalışmanın amac1, 2010-2013 yıllarında Türkiye İstatistik Kurumu'nun gerçekleştirmiş olduğu Gelir ve Yaşam Koşulları (Panel) araştırması verileri kullanılarak toplumsal ve ekonomik yoksunluk yaşayan bireylerin maruz kaldığı sosyal dışlanma olgusunu etkileyen etmenleri Panel Regresyon Modeli ile analiz etmektir. Sosyal dışlanma kavramı ile ilgili yapılan çalışmalar incelendiğinde, genelde teorik çalışmaların olduğu ve sınırlı sayıda yoksullukla ilişkisinin incelendiği görülmektedir. Literatürde bireysel bazda bir sosyal dışlanma indeksi oluşturularak bireylerin sosyal dışlanmasını etkileyen etmenlerin incelendiği bir ekonometrik çalışmaya rastlanmamıştır. Analizlerden elde edilecek bilgiler ışı̆̆ında, günümüzün hemen hemen tüm ülkelerde farklı şekillerde karşımıza çıkan ve ülkelerin sosyal politikalarına da dahil ettiği sosyal dışlanma sorununun somut olarak ortaya konması ve çözüm önerilerinde bulunulması hedeflenmektedir.

$\mathrm{Bu}$ çalışmanın izleyen bölümleri şu şekilde düzenlenmiştir. İkinci bölümde konuyla ilgili literatür araştırması ele alınmıştır. Üçüncü bölümde çalışmada kullanılan panel veri analizi sunulmuştur. Çalışmanın ekonometrik analiz kısmını oluşturan dördüncü bölümünde ise, kullanılan verilere ait tanımlayıcı istatistiklere ve analizlerden elde edilen bulgulara yer verilmiştir. Son olarak sonuç bölümünde model tahminlerinden elde edilen bulgular literatürdeki çalışmalarla desteklenerek yorumlanmıştır.

\section{Literatür araştırması}

Literatürde sosyal dışlanma kavramı ile ilgili yapılan çalışmalara bakıldığında ampririk çalışmaların sınırlı ve çok az sayıda olduğu görülmektedir. İlgili literatür aşağıda sunulmuştur.

Bhalla \& Lapeyre (1997), dışlanma kavramının ekonomik, sosyal ve siyasal boyutları bulunduğunu fakir toplumlarda, dışlanmanın temelinde ekonomik dışlanma sorununun olduğunu tespit etmiştir. Ayrıca siyasi özgürlük, sivil hak ve özgürlüklerin sınırının çizilmesi durumunda ekonomik dışlanmanın üstesinden gelinebileceğini açıklanmıştır. Farringhton (2002), sosyal dışlanma kavramının tanımlarını yaptığı çalışmasında sosyal dışlanma kavramını, dezavantajlarıyla tanımlamanın bir yol olduğunu ancak bunun yetersiz kalacağını belirtmiştir. Sosyal dışlanma, toplum dışındaki kişiler tarafından yaşanan, toplumsal farklılıkları ayıran ve bu farklılıklardan doğan sorunları şiddetlendirmeyen bir kavramdır. Ayrıca Farringhton (2002), en uygun tanımlamanın insanların veya çevrelerinin devletin sosyal, ekonomik ve siyasal alanda yaşandıkları dışlanma olduğunu belirtmektedir.

Tsakloglou ve Papadopulos (2002), Avrupa nüfusunda sosyal dışlanmaya maruz kalacak yüksek risk altındaki üyeleri incelemiştir. Sosyal dışlanmanın dinamik olduğu fikrini takiben yoksunluk statik göstergelerini (gelir, yaşam koşulları, yaşam ve toplumsal ilişkilerde ihtiyaçlar) belirlemiştir. Bireylerin 3 yılda en az iki defa sosyal dışlanma yaşama risklerinin olduğu belirtilmiştir. Poggi (2007), özellikle bireysel olarak sosyal dışlanmaya yol açan nedenleri analiz etmiş ve önceden sosyal dışlanmaya maruz kalan bireylerin sonrasında da sosyal dışlanma ile karşılaşmasının daha muhtemel olduğunu görmüştür. Sosyal dışlanmayı görünen ve görünmeyen olarak ikiye ayırmış ve öncesinde sosyal dışlanmanın yaşanılmasının sonrasında da yaşanma olasılığını arttırdığg sonucuna ulaşmıştır. Gülberk (2009), deney yöntemini kullanarak sosyal 
Selim, S., Çomuk, P., (2017). Yoksunluk yaşayan bireyler sosyal dışlanmaya maruz kalır mı? Türkiye örneği. International Journal of Social Sciences and Education Research, 3 (3), 1041-1053.

dışlanma, aidiyat ihtiyacı ve tüketim değişkenleri ile yaptı̆̆ çalışmasında, sosyal dışlanmanın bir gruba bağl1lı̆̆ simgeleyen ürünler hakkındaki yorumları pozitif yönde etkilediğini gözlemlemiştir. Çalışmada dışlanan kişilerin dışlanmayanlara göre bir gruba bağlı ürünleri almaya daha yatkın oldukları belirlenmiştir.

Şenol (2010), işsizliğin sosyal dışlanma üzerindeki etkilerini incelediği çalışmasında, alan araştırması yöntemini kullanmıştır. Elde ettiği sonuçlara bakıldığında, işsizliğin sosyal dışlanma üzerinde oldukça yüksek düzeyde etkisinin bulunduğunu ve işsizlerin çalışanlara göre çok daha yüksek bir düzeyde sosyal dışlanmaya maruz kaldıklarını istatistiksel verilerle ortaya koymuştur. Özbek (2010), 1990'lı yılların başından itibaren Tuzla Belediyesi sınırları içerisinde tarlalarda çalışan ve çadırlarda yaşayan tarım işçilerinin çocuklarının yaşam ve çalışma koşullarını, sosyoekonomik durumlarını ve eğitim durumlarını incelemiştir. Aileleriyle birlikte yaşamlarını sürdüren çocukların yoksulluk, yoksunluk ve sosyal dışlanma olguları ile birebir karşılaştıkları vurgulanmıştır. Bu durumun ayrıca çocuk işçiliğine yol açtığını ve çocuk işçilerinin de yoksulluk, yoksunluk, sosyal dışlanma ve vatandaşlık haklarından yararlanamadıklarını göstermiştir. Özgökçeler ve Bıçkı (2010), görüşme yöntemini kullanarak sosyal dışlanma, yoksulluk, özürlülük değişkenlerini incelediği çalışmasında Bursa ve Çanakkale Kent Konseylerinde yer alan ve çoğunluğunu ortopedik özürlü erkek bireylerin oluşturduğu bir grupla çalışmış ve özürlü kadın bireylerin istihdam olanaklarından yeteri kadar yararlanamadığını görmüştür. Ancak üniversite mezunu olan özürlü kadınların; insana yakışır, güvenceli bir işte istihdam edildiği tespit edilmiştir. Bu anlamda kaliteli ve yüksek eğitim seviyesi, hem özürlü hem de kadın olduğu için ikili dışlanmaya maruz kalan kesimler açısından bir "çıkış noktası" oluşturabilmektedir. Özürlü bireylerin mülkiyetten dışlanma şeklinde ifade edilen bir sosyal dişlanma formuna sahip olmadıklarının tespit edildiği çalışmada özürlü bireylerin çok büyük bir bölümünün eğitim hizmetlerinden yeteri kadar yararlanamadığı saptanmıştır. $\mathrm{Bu}$ durum kendilerinin eğitim imkânlarından dışlandığını da göstermiştir.

Habib (2015), sosyal dışlanma, yaşlıların seyahat özellikleri ve seyahat mesafesi değişkenlerini kullanarak yaptığı çalışmasında, 65 yaş üstü yaşlıların seyahat mesafelerini etkiyen etmenler ile yaşadıkları sosyal dışlanma arasındaki ilişkiyi araştırmıştır. Ampirik modelde Kanada Ulusal Başkent Bölgesinde yaşayan yaşlıların çeşitli faaliyetler gerçekleştirebilmeleri için uzak mesafeli seyahatler yapmaları gerektiği ortaya çıkmıştır. Ayrıca çalışmadan elde edilen bulgulara göre artan yaşlı nüfusla birlikte ulaştırma kaynaklı sosyal dışlanmanın yaşanma riskini arttırdığ 1 görülmüştür. Genç vd. (2015), yarı yapılandırılmış görüşme yöntemi ile yaptığ1 çalışmasında, eğitim sürecinden ve sosyal hayattan dışlanma riskiyle karşı karşıya olan Roman çocuklarının eğitim süreçlerindeki başarı trendlerinin olumsuz etkilendiği ve toplumla bütünleşme sorunu yaşadıkları sonucuna ulaşmıştır.

\section{Metodoloji}

Bu çalışmanın amac1, 2010-2013 yıllarında Türkiye İstatistik Kurumu'nun gerçekleştirmiş olduğu Gelir ve Yaşam Koşulları (Panel) araştırması verileri kullanılarak toplumsal ve ekonomik yoksunluk yaşayan bireylerin maruz kaldığ 1 sosyal dışlanma olgusunu etkileyen etmenleri Panel Regresyon Modeli ile analiz etmektir.

Panel veri analizi, en genel anlamıyla zaman boyutuna sahip yatay-kesit serilerini kullanarak ekonomik ilişkilerin tahmin edilmesine ilişkin yöntem olarak tanımlanabilmektedir. Bu analizde zaman serileri ile yatay-kesit serileri bir araya getirilerek hem zaman hem de kesit boyutuna sahip 
Selim, S., Çomuk, P., (2017). Yoksunluk yaşayan bireyler sosyal dışlanmaya maruz kalır mı? Türkiye örneği. International Journal of Social Sciences and Education Research, 3 (3), 1041-1053.

veri seti oluşturulabilmektedir (Demirhan, 2009: 80). Panel veri modellerinin sıradan zaman serisi ve/veya kesit modellere göre önemli üstünlükleri vardır. Bu modellerde gözlem sayısı kesit ve zaman serilerine göre daha fazla olacak ve böylece elde edilecek parametre tahminleri daha güvenilir hale gelecektir. Ayrıca tahmin edilen modeller daha az kısitlayıcı varsayımlara dayanacaktır. Panel veri modelleri diğer yöntemlere nazaran daha karmaşık davranış modellerinin kurulmasına ve test edilmesine olanak verir. Panel veri kullanmanın bir başka üstünlüğü de; sadece birimler arası farklılıkların araştırılabildiği kesit verileriyle yapılan tahminlerin aksine, gerek birimler gerekse bir birimin içerisinde zamana göre meydana gelen farklılıkların birlikte incelenebilmesine olanak vermesidir (Baltagi, 2001: 3-5).

Panel veri analizi zaman boyutu da olduğundan dinamik bir modelin kurulmasına olanak sağlamaktadır. Ayrıca ihmal edilmiş değişkenlerden kaynaklanan problemlerin ve tahmin sapmalarının azaltılmasına ve birimlere ilişkin davranışların daha iyi tahminine imkan vermektedir. Panel veri analizinin avantajları yanında bazı dezavantajları da bulunmaktadır. Belirli dönemlerde ankete katılan birimlere ulaşılamaması ve/veya ulaşılan birimlerden yanıt alınamaması, eksik cevap alınması, cevapların hatırlanamaması vb. nedenlerle panel veri analizlerinde verilerin elde edilmesi ve düzenlenmesi aşamasında bazı sorunlarla karşılaşılmaktadır. Her birim için zaman serisi boyutunun kısa olabilmesi, veri seti geniş olduğu için panel verilerde zaman zaman ölçüm hatalarının olabilmesi ise diğer dezavantajları olarak ifade edilebilir (Timurçin, 2010: 218).

Panel veri modeli aşağıdaki eşitlikteki gibi ifade edilmektedir:

$$
Y_{i t}=\beta_{1 i t}+\beta_{2 i t} X_{2 i t}+\ldots .+\beta_{k i t} X_{k i t}+\varepsilon_{i t} \quad i=1, \ldots, N \quad t=1, \ldots, T
$$

Burada $N$ birimleri göstermekte, $t$ ise zamanı göstermektedir. $Y$ değişkeni, birimden birime ve bir zaman periyodundan ardışık zaman periyoduna farklı değerler almakta olan bağımlı bir değişken olduğunda, kesit boyutu için $i$ ve zaman periyodu için $t$ olmak üzere iki alt indisle ifade edilmektedir. Genel model sabit ve regresyon parametrelerinin her bir zaman periyodunda her bir birey için ayrılmasına izin vermektedir. Çalışkan (2009:124)'e göre ise, sabit etkiler modeli (fixed effects) ve rassal etkiler modeli (random effects) olmak üzere iki temel yaklaşımın söz konusu olduğu $K$ değişkenli panel veri modeli;

$$
y_{i t}=\beta_{1 i t}+\beta_{2 i t} X_{2 i t}+\ldots .+\beta_{K i t} X_{K i t}+\varepsilon_{i t}
$$

biçiminde gösterilmektedir. Modelde $i=1, \ldots, N$ yatay kesit birimlerini ve $t=1, \ldots, T$ zamanı gösterirken, olasılıklı olmayan hata terimi $\varepsilon$ 'nun ortalamasının sıfır ve sabit varyanslı olduğu varsayılmaktadır. Buna göre; $y_{i t}$, i'nci yatay kesit biriminin $t$ zamanında bağımlı değişken değerini; $X_{K i t}$, i'nci yatay kesit biriminin $t$ zamanında $K$ 'nıncı açıklayıcı değişken değerini; $\beta_{\text {Kit, }}$ $i$ 'inci birim ve $t$ 'inci zaman dönemi için $K$ 'ıncı açıklayıcı değişkenin tahmin edilen katsayısını göstermektedir (Baltagi, 2011:11).

Katsayıların birimlere veya birimler ile zamana göre değiştiğinin varsayıldığı modellere "Sabit Etkili Modeller" denmektedir. Denklem (2)'de ifade edilen modelde, (Griffits ve Carte, 1993:571573)'e göre, katsayılar farklı birimler için farklı zaman periyodlarında farklı değerler almaktadır. $\mathrm{Bu}$ durumda tahmin edilen parametre sayısı, kullanılan gözlem sayısını aşmakta, diğer ifadeyle model tahmin edilememektedir. Bu dezavantaj nedeniyle panel veriyle yapılan çalışmalarda daha çok hata terimlerinin özellikleri ve katsayıların değişebilirliğiyle ilgili farklı varsayımlarda bulunularak farklı modeller elde edilebilmektedir. Farklı varsayımlarla elde edilen modeller "sabit etkili" ve "tesadüfî etkili" modellerdir. Her iki modelde de $e_{i t}$ hatalarının tüm zaman 
Selim, S., Çomuk, P., (2017). Yoksunluk yaşayan bireyler sosyal dışlanmaya maruz kalır mı? Türkiye örneği. International Journal of Social Sciences and Education Research, 3 (3), 1041-1053.

dönemlerinde ve tüm bireyler için bağımsız ve $\mathrm{N}\left(0, \sigma_{\mathrm{e}}^{2}\right)$ şeklinde dağıldığ $\breve{g}_{1}$ varsayılmaktadır (Hsiao, 1986: 30). Model seçiminde sabit etki veya tesadüfi etki modelinin uygun olup olmadığına karar verilmesi için "Hausman spesifikasyon testi" kullanılmakta ve bu testte $\mathrm{H}_{0}$ hipotez bireysel etkilerin modeldeki diğer açıklayıcı değişkenlerle ilişkisiz olduğunu (tesadüfî etkinin varlığını) belirtmektedir. $\mathrm{H}_{0}$ hipotezinin reddedilmesi ise sabit etki modelinin tercih edilmesi gerektiğini göstermektedir (Berke, 2009: 41). Bu çalışmada Hausman testi sonucu, sabit etkili panel veri regresyon modelinin tercih edilmesi gerektiğini göstermektedir.

\section{Ekonometrik analiz}

\section{1 Çalışmada kullanılan veriler}

Bu çalışmada panel veri modelinde kullanılan bağımlı değişken sosyal dışlanma indeksidir. Sosyal dışlanma indeksinin elde edilmesinde kullanılan göstergeler Tablo 1'de sunulmuştur.

Tablo 1. Sosyal dışlanma indeksinin elde edilmesinde kullanılan değişkenler

\begin{tabular}{|c|c|}
\hline 1. & Ferdin Fiziksel Yeterlilik Durumu \\
\hline 2. & Ferdin sosyal güvenlik durumu \\
\hline 3. & Ferdin yoksul olup olmadığ1 \\
\hline 4. & Ferdin konutunun mülkiyeti \\
\hline 5. & Oturulan konutta banyo/duş durumu \\
\hline 6. & Oturulan konutta tuvalet durumu \\
\hline 7. & Oturulan konutta bağımsız mutfak durumu \\
\hline 8. & Oturulan konutta borulu su sistemi durumu \\
\hline 9. & Oturulan konutta sicak su sistemi durumu \\
\hline 10. & Oturulan konutta telefon hattı durumu \\
\hline 11. & Hane halkının cep telefonuna sahip olma durumu \\
\hline 12. & Hane halkının renkli televizyona sahip olma durumu \\
\hline 13. & Hane halkının bilgisayara sahip olup olmaması \\
\hline 14. & Hane halkının internete sahip olma durumu \\
\hline 15. & Hane halkının otomatik çamaşır makinesine sahip olma durumu \\
\hline 16. & Hane halkının buzdolabına sahip olma durumu \\
\hline 17. & Hane halkının bulaşık makinesine sahip olma durumu \\
\hline 18. & Hane halkının klimaya sahip olma durumu \\
\hline 19. & Hane halkının otomobile sahip olma durumu \\
\hline 20. & $\begin{array}{l}\text { Son } 12 \text { ay içinde ev kirasının, faizli borç geri ödemesinin veya konut kredisinin planlandığı gibi } \\
\text { ödenememe durumu }\end{array}$ \\
\hline 21. & Son 12 ay içinde elektrik, su, gaz faturalarının planlandığı gibi ödenememe durumu \\
\hline 22. & $\begin{array}{l}\text { Son } 12 \text { ay içinde taksit, kredi kart1 ve diğer borç ödemelerinin planlandığı gibi ödenememe } \\
\text { durumu }\end{array}$ \\
\hline 23. & $\begin{array}{l}\text { İstenildiği veya ihtiyaç duyulduğu zaman tüm hane halkı fertleri birlikte evden uzakta bir haftalık } \\
\text { tatili karşlayabilecek durumda olup olmama durumu }\end{array}$ \\
\hline 24. & $\begin{array}{l}\text { İstenildiği veya ihtiyaç duyulduğu zaman en az üç gün et, tavuk ya da balık içeren yemeği } \\
\text { karşlayabilme durumu }\end{array}$ \\
\hline 25. & Evin ısınma ihtiyacının yeterince karşılanabilme durumu \\
\hline 26. & Yıpranmış veya eskimiş mobilyaları yenileyebilme durumu \\
\hline 27. & Yeni giysiler alabilme durumu \\
\hline
\end{tabular}

Sosyal dışlanma indeksi oluşturulurken Filmer ve Pritchett (2006)'de kullanılan istatistiksel yaklaşım ele alınmıştır. Bu yaklaşıma göre,

$\mathrm{a}^{*}{ }_{1 \mathrm{j}}$ den $\mathrm{a}^{*}{ }_{\mathrm{N}}$ 'ye kadar her fert için j'den N'ye kadar temsil edilen bir dizi $\mathrm{N}$ değişkenin olduğunu varsayalım. 
Selim, S., Çomuk, P., (2017). Yoksunluk yaşayan bireyler sosyal dışlanmaya maruz kalır mı? Türkiye örneği. International Journal of Social Sciences and Education Research, 3 (3), 1041-1053.

Temel bileşenler analizi, her değişkenin ortalama ve standart sapmaları ile normalize edilerek başlayacaktır. Örneğin:

$\mathrm{a}_{1 \mathrm{j}}=\left(\mathrm{a}^{*}{ }_{1 \mathrm{j}}-\mathrm{a}^{*}{ }_{1}\right) /\left(\mathrm{s}_{1}{ }_{1}\right)$, burada, $\mathrm{a}{ }_{1}$ birinci değişkene ait ortalamay1, $\mathrm{s}{ }_{1}$ birinci değişkene ait standart sapmayı göstermektedir. Bu değişkenler, her fert j için bir dizi doğrusal kombinasyonları ifade etmektedir:

$$
\begin{gathered}
a_{1 j}=v_{11} \times A_{1 j}+v_{12} \times A_{2 j}+\ldots+v_{1 N} \times A_{N j} \ldots \\
a_{N j}=v_{N 1} \times A_{1 j}+v_{N 2} \times A_{2 j}+\ldots+v_{N N} \times A_{N j},
\end{gathered}
$$

(3) nolu denklemden elde edilen "faktörler" ile her biri için tahmin bir dizi $N$ temel bileşenleri elde edilmiştir.

$$
\begin{array}{ll}
A_{1 j}=f_{11} \times a_{1 j}+f_{12} \times a_{2 j}+\ldots+f_{l N} \times a_{N j \ldots} . & j=1, \ldots J \\
A_{N j}=f_{N 1} \times a_{1 j}+f_{N 2} \times a_{2 j}+\ldots+f_{N N} \times a_{N j .} &
\end{array}
$$

İlk temel bileşen, orijinal (normalleştirilmemiş) değişkenler ile ifade edilir ve her fert için bir endeks oluş̧urulur.

$$
A_{1 j}=f_{11} \times\left(a *_{1 j}-a *_{1}\right) /\left(s^{*}\right)+\ldots+f_{l N} \times\left(a *_{N j}-a *_{N}\right) /\left(s_{N}\right) .
$$

$\mathrm{Bu}$ çalışmada önemli olan varsayım, yoksunluk değişkenlerinin maksimum varyansının her bir fert için uzun vadede yoksunluğu açıklıyor olmasıdır.

Sosyal dışlanmayı belirleyen etmenleri incelemek için kullanılan bağımsız değişkenler ise yaş, cinsiyet, eğitim durumu, medeni durum, oturulan konuttaki mülkiyet şekli, ferdin genel sağlık durumu, ferdin kanun yapıcılar, üst düzey yöneticiler ve müdürler/ profesyonel meslek mensubu olarak çalışıp çalışmadığıdır.

\subsection{Tanımlayıcı istatistikler}

$\mathrm{Bu}$ çalışmada modelde kullanılan değişkenlere ait tanımlayıcı istatistikler Tablo 2'de sunulmuştur. Tablo 2 incelendiğinde, ankete katılanların \%49,3'ünü erkek \% 50,7'sini ise kadınlar oluşturmaktadır. Bireylerin yaşları incelendiğinde, \%27,4'ünün 15 yaş ve altı olduğu, $\% 13,5$ 'inin 35-44 yaş arası ve \%16'sının 55 yaş ve üstünde olduğu görülmektedir. Ankete katılanların \%21,9'u eğitimsizlerden, \%33,5'i ilkokul/ortaokul, mesleki ortaokul ve ilköğretim, $\% 19,5$ 'i genel lise, \%15,7'si mesleki veya teknik lise, \%9'u yüksekokul, fakülte ve üzeri mezunlardan oluşmaktadır. Konutun mülkiyet şekline bakıldığında, bireylerin \%64,1'i ev sahibi, \% 19,5'i kiracı ve \%1'i lojmanda yaşamaktadır. Ankete katılanların genel sağlık durumlarına bakıldığında \%65,3'ünün iyi, \%20,5'inin orta, \%14,3’ünün kötü olduğu görülmektedir. Medeni durumlarına bakıldığında, bireylerin \%91,2'si evli, eşinden boşanmış veya eşi ölmüş, \%8'i hiç evlenmemiştir. Meslek grubuna bakıldığında \%5'inin kanun yapıcılar, üst düzey yöneticiler ve müdürler/ profesyonel meslek mensupları olduğu ve \%95 'lik kısmının diğer meslek grubuna mensup bireyler olduğu görülmektedir. 
Selim, S., Çomuk, P., (2017). Yoksunluk yaşayan bireyler sosyal dışlanmaya maruz kalır mı? Türkiye örneği. International Journal of Social Sciences and Education Research, 3 (3), 1041-1053.

Tablo 2. Tanımlayıcı istatistikler

\begin{tabular}{|c|c|c|}
\hline & Ortalama & Standart Sapma \\
\hline Sosyal Dışlanma İndeksi & 0 & 1 \\
\hline \multicolumn{3}{|l|}{ Cinsiyet } \\
\hline Erkek & 0.493 & 0.500 \\
\hline Kadın (Temel sinıf) & 0.517 & 0.500 \\
\hline \multicolumn{3}{|l|}{ Yaş } \\
\hline 15 yaş altı (Temel sınıf) & 0.274 & 0.446 \\
\hline $15-24$ & 0.162 & 0.369 \\
\hline $25-34$ & 0.154 & 0.361 \\
\hline $35-44$ & 0.135 & 0.342 \\
\hline $45-54$ & 0.115 & 0.319 \\
\hline $15-24$ & 0.160 & 0.367 \\
\hline \multicolumn{3}{|l|}{ Eğitim } \\
\hline Eğitimsizler (Temel sınıf) & 0.219 & 0.414 \\
\hline İlkokul/Ortaokul, mesleki ortaokul ve ilköğretim & 0.335 & 0.472 \\
\hline Genel lise & 0.195 & 0.396 \\
\hline Mesleki veya teknik lise & 0.157 & 0.364 \\
\hline Yüksekokul,fakülte ve üzeri & 0.093 & 0.290 \\
\hline \multicolumn{3}{|l|}{ Konutun Mülkiyet Şekli } \\
\hline Ev sahibi (temel sınıf) & 0.641 & 0.480 \\
\hline Kirac1 & 0.195 & 0.396 \\
\hline Lojman & 0.016 & 0.124 \\
\hline Diğerleri & 0.148 & 0.356 \\
\hline \multicolumn{3}{|l|}{ Ferdin Genel Sağlık Durumu } \\
\hline Sağllk durumu iyi (Temel sınıf) & 0.653 & 0.476 \\
\hline Sağlik durumu orta & 0.205 & 0.403 \\
\hline Sağllk durumu kötü & 0.143 & 0.350 \\
\hline \multicolumn{3}{|l|}{ Medeni Durum } \\
\hline Evli, Eşinden Boşanmış ve Eşi ölmüş (Temel sınıf) & 0.912 & 0.430 \\
\hline Hiç evlenmedi & 0.088 & 0.284 \\
\hline \multicolumn{3}{|l|}{ Ferdin Meslek Grubu } \\
\hline $\begin{array}{l}\text { Kanun Yapıcılar, Üst Düzey Yöneticiler ve } \\
\text { Müdürler/ Profesyonel Meslek Mensupları }\end{array}$ & 0.056 & 0.231 \\
\hline $\begin{array}{l}\text { Yardımcı Profesyonel Meslek Mensupları Büro ve } \\
\text { Müşteri Hizmetlerinde Çalışan Elemanlar /Hizmet } \\
\text { ve Satış Elemanları/ Nitelikli Tarım, Hayvancılık, } \\
\text { Avcılık, Ormancılık ve } \quad \text { Su Ürünleri } \\
\text { Çalışanları/Sanatkarlar ve İlgili İşlerde } \\
\text { Çalışanlar/Tesis ve Makine Operatörleri ve } \\
\text { Montajcıları/Nitelik Gerektirmeyen Işlerde } \\
\text { Çalışanlar/Çalışmayanlar (Temel sınıf) }\end{array}$ & 0.944 & 0.408 \\
\hline Örnek Hacmi & 102,095 & \\
\hline
\end{tabular}

\subsection{Bulgular}

Tablo 3'de sabit etkiler panel regresyon modeli sonucu verilmiştir. Hausman testi, panel veri modellerinden sabit etkiler modelinin kabul edilmesi gerektiğini gösterir. Aynı zamanda F testi, birim etkinin varlığına göre panel verinin kullanılacağını göstermektedir. 
Selim, S., Çomuk, P., (2017). Yoksunluk yaşayan bireyler sosyal dışlanmaya maruz kalır mı? Türkiye örneği. International Journal of Social Sciences and Education Research, 3 (3), 1041-1053.

Tablo 3. Sabit etkiler panel regresyon modeli tahmini

\begin{tabular}{|l|l|l|l|}
\hline Bağımlı değişken: Sosyal Dışlanma İndeksi & Katsayı & t değeri & Olasılık \\
\hline Cinsiyet & & & \\
\hline Erkek & 0.002 & 1.83 & $0.067^{* * *}$ \\
\hline Yaş & 0.00004 & 1.95 & $0.051^{* * *}$ \\
\hline Eğitim & & & \\
\hline İlkokul/Ortaokul, mesleki ortaokul ve ilköğretim & -0.063 & -6.63 & $0.000^{*}$ \\
\hline Genel lise & -0.036 & -3.80 & $0.000^{*}$ \\
\hline Mesleki veya teknik lise & -0.045 & -4.34 & $0.000^{*}$ \\
\hline Yüksekokul,fakülte ve üzeri & -0.090 & -6.82 & $0.000^{*}$ \\
\hline Konutun Mülkiyet Şekli & & & \\
\hline Kiracı & 0.090 & 12.96 & $0.000^{*}$ \\
\hline Lojman & -0.352 & -11.55 & $0.000^{*}$ \\
\hline Diğerleri & 0.135 & 16.37 & $0.000^{*}$ \\
\hline Ferdin Genel Sağlık Durumu & & & \\
\hline Sağlik durumu orta & 0.020 & 13.91 & $0.000^{*}$ \\
\hline Sağlik durumu kötü & 0.034 & 16.94 & $0.000^{*}$ \\
\hline Medeni Durum & & & \\
\hline Hiç evlenmedi & 0.232 & 42.29 & $0.000^{*}$ \\
\hline Ferdin Meslek Grubu & & & \\
\hline $\begin{array}{l}\text { Kanun Yapı̈ılar, Üst Düzey Yöneticiler ve } \\
\text { Müdürler/ Profesyonel Meslek Mensupları }\end{array}$ & -0.008 & -1.90 & $0.058^{* * *}$ \\
\hline $\begin{array}{l}\text { F (42268, 59813) } \\
\text { Hausman Testi }\end{array}$ & 156.10 & & \\
\hline$\chi^{2}(13)$ & & & 0.000 \\
\hline N (örnek hacmi) & 5514.99 & & 0.000 \\
\hline$* *$ & 102095 & & \\
\hline
\end{tabular}

Not: *** ve ***, srrasıyla katsayıların $0.01,0.5$ ve 0.10 önem seviyesinde anlamlı olduğunu gösterir.

Tablo 3 incelendiğinde, tüm bağımsız değişkenlerinin sosyal dışlanma indeksi üzerinde anlamlı bir etkisinin bulunduğu görülmektedir. Model sonuçlarına göre erkekler kadınlara göre daha fazla sosyal dışlanmaya maruz kalmıştır. Habib (2015), çalışmasında 65 yaş üstü bireylerin sosyal dışlanmaya maruz kaldığını belirtirken, bu çalışmada da yaş arttıkça ferdin sosyal dışlanmasının arttığı görülmüştür. Eğitim durumuna bakıldığında ilkokul/ortaokul, mesleki ortaokul ve ilköğretim, genel lise, mesleki veya teknik lise, yüksekokul, fakülte ve üzeri olanlar okur-yazar olmayan/okur-yazar olup okul bitirmeyenlere göre daha az sosyal dişlanmaya maruz kalmıştır. En az sosyal dışlanma yüksekokul ve üzeri eğitim düzeyinde görülmektedir. Konutun mülkiyet şekli lojman olanlar ev sahibi olanlara göre daha az dışlanma yaşarken, kiracı olanlar ve diğer konutlarda yaşayanlar ev sahibi olanlara göre daha fazla dışlanma yaşamışlardır. Ferdin genel sağlık durumu kötü ve orta düzeyde olanlar sağlık durumu iyi olanlara göre daha fazla yoksundur ve daha çok sosyal dışlanmışlardır. Ferdin medeni durumu incelendiğinde ise hiç evlenmeyenler, evli, eşi ölmüş, boşanmış ve ayrı yaşayanlara göre daha fazla yoksunluk çekmektedir. Kanun yapıcılar, üst düzey yöneticiler ve müdürler ile profesyonel meslek mensuplarının diğer işlerde çalışanlara göre daha az yoksunluk çektiği ve sosyal dışlanmaya maruz kaldığı görülmektedir. Tüm değişkenler dikkate alındığında sosyal dışlanma üzerinde en önemli değişkenlerin medeni durum, konutun mülkiyet şekli ve özellikle bireyin yüksekokul mezunu olduğu sonucuna ulaşılmıştır. 
Selim, S., Çomuk, P., (2017). Yoksunluk yaşayan bireyler sosyal dışlanmaya maruz kalır mı? Türkiye örneği. International Journal of Social Sciences and Education Research, 3 (3), 1041-1053.

\section{Sonuc}

Sosyal dışlanma, toplumsal kesimlerin ve bireylerin toplumsal ilişkilerden ve yaşamdan yeterince veya bütünüyle faydalanamamaları ve fiziksel olarak o toplumun içinde olsalar dahi sosyal katılım gerçekleştirememeleri durumudur (Çakır, 2002:83). Bireylerin yaşamış oldukları ekonomik, toplumsal ve siyasi yoksunluklar, bireyleri toplumun dışına itmesiyle ya da bireylerin kendilerini toplumdan uzaklaştırması, sosyal dışlanma yaşamalarına neden olmaktadır.

Çalışmadan elde edilen bulgulara göre Türkiye'deki fertlerin cinsiyet, yaş, eğitim, konutun mülkiyet şekli, ferdin genel sağlik durumu, medeni durumu ve meslek grubu değişkenlerinin yoksunluk üzerinde anlamlı bir etkisi bulunduğu görülmüştür. Öztürk ve Çetin (2009), çalışmasında kadın ve çocukların erkeklere göre daha fazla yoksunluktan dolayı dışlandığını belirtirken, bu çalışmada bunun aksine erkekler kadınlara göre daha fazla sosyal dışlanmaya maruz kalmıştır. Eğitim durumuna bakıldığında eğitim düzeyi arttıkça sosyal dışlanma azalmaktadır. Konutun mülkiyet şekli lojman olanlar ev sahibi olanlara göre daha az ve kiracı olanlar ve diğer konutlarda yaşayanlar ev sahibi olanlara göre daha fazla yoksunluk yaşamaktadır ve dışlanmaktadır. Ferdin genel sağlık durumu kötüye gittikçe sosyal dışlanma durumu da artmaktadır. Ferdin medeni durumuna bakıldığında ise bekarlar diğerlerine göre büyük oranda sosyal dışlanmaya maruz kalmışlardır. Sonuç olarak, Hekimler (2012)'in de belirttiği gibi tüm dünyada yaşanan gelişmeler, sosyal dışlanmanın çok boyutlu bir yoksunluk süreci olduğunu, bu durumda siyasal, sosyal ve kültürel unsurların da bu sürece dahil edilmesi gerektiğini göstermektedir. Sosyal, iktisadi ve yeterlilikten yoksunluk çeken bireyler sosyal dişlanmaya maruz kalmakta ve onların yaşamlarını olumsuz etkilemektedir. Bireylerin yoksunluklarını azaltarak sosyal dışlanma yaşamalarını engellemek için ülkeler sosyal politikalarını belirlerken sosyal dışlanma ile ilgili önemli kararlar almaları gerekmektedir.

\section{Kaynaklar}

Baltagi, B. H. (2001). Econometric analysis of panel data, 2nd Edition, Chichester: John Wiley \& Sons Ltd.

Berke, B. (1999). Avrupa parasal birliğinde kamu borç stoku ve enflasyon ilişkisi: panel veri analizi. İstanbul Üniversitesi İktisat Fakültesi Ekonometri ve İstatistik Dergisi, Sayı:9, 30-55.

Bhalla, A., \& Lapeyre F. (1999).Poverty and Exclusinn in a Global World. MacMillan Press Ltd., London.

Bölükbaşı, B.(2008). Türkiye'de sosyal dışlanma ve yoksulluk. Marmara Üniversitesi, Sosyal Bilimler Enstitüsü, Çalışma Ekonomisi Ve Endüstri İlişkileri Anabilim Dalı, Çalışma Ekonomisi Bilim Dalı, Yüksek Lisans Tezi, İstanbul, 79.

Çakır, Ö. (2002). Sosyal dışlanma. Dokuz Eylül Üniversitesi Sosyal Bilimler Enstitüsü Dergisi.4 (3),83104.

Çalışkan V. (2009). Geography of a hidden cultural heritage: camel wrestles in Western Anatolia, Uluslararası Sosyal Araştırmalar Dergisi. The Journal of International Social Research. 2/8. 123-137.

Dağdemir, Ö. (2002). Türkiye ekonomisinde yoksulluk sorunu ve yoksulluğun analizi: 19871994.Yoksullukla Mücadele Stratejileri, Ankara, Hak-Işs Konfederasyonu Yayını, , s. 1.

Demirhan, A. (2009). Bankaların sektörel paylarindaki değişimin nitel bağımlı değişkenli panel veri modeliyle analizi. İstanbul Üniversitesi İ̧sletme Fakültesi İşletme İktisadı Enstitüsü Dergisi-Yönetim, 20(64), 78-97. 
Selim, S., Çomuk, P., (2017). Yoksunluk yaşayan bireyler sosyal dışlanmaya maruz kalır mı? Türkiye örneği. International Journal of Social Sciences and Education Research, 3 (3), 1041-1053.

De Haan, A.(1998), Social exclusion in policy end research: operationalizing the concept, (Ed.) J. B. Figuiredo ve Arjan De Haan, Social Exclusion: An ILO Perspective, Intenational Institute for Labour Studies [IILS], Geneva, 367-369.

Evans, P. ve Deluca, M. (2000), Social exclusion and children ,Creating Identity Capital: Some Conceptual Issues and Practical Solutions, s.1.

Farrington, F. (2002). Towards a useful definition: advantages and criticisms of socialexclusion, internet erişim: file:///C:/Users/Casper/Downloads/12-49-1-PB.pdf.(14.12.2016).

Genç, Y. , Taylan, H. H.\&Barış, İ.(2015), Roman çocuklarının eğitim süreci ve akademik başarılarında sosyal dışlanma algısının rolü, The Journal of Academic Social Science Studies, International Journal of Social Science, Number: 33 . 79-97.

Griffiths, W., Hill, E. R. C., \& Judge, G. G. (1993). Learning and practicing econometrics. Canada: John Wiley \& Sons.

Gülberk, Yıldırım, (2009).Sosyal dışlanma kişileri aidiyat ihtiyaçlarını karşılamak için tüketime teşvik ediyor mu?, Bilkent Ünivesitesi , İsletme Bölümü, Yüksek Lisans Tezi, Ankara.

Habib, K., N.(2014). An İnvestigation On Mode Choice And Travel Distance Demand Of Older People İn The National Capital Region (NCR) Of Canada: Application Of A Utility Theoretic Joint Econometric Model . Springer Science+Business Media New York.

Hekimler, O. (2012). Yoksulluk Mu Yoksunluk Mu? Sosyal Dışlanma Üzerine Bir Değerlendirme. Tekirdă̆ S.M.M.M. Odası Sosyal Bilimler Dergisi, Eylül,Sayı:1.

Hsiao, C. (1986). Analysis of panel data. Cambridge University Press, UK.

Özbek, A. (2010). Yoksulluk Ve Sosyal Dışlanma Bağlamında Çocuk İşçilerin Sosyolojik Analizi - Çocuk Yoksulluğu İle Mücadele, Uluslararası Yoksullukla Mücadele Stratejileri Sempozyumu Bildiri Kitabı, İstanbul, 443-454.

Özgökçeler, S.t; Bıçk1, D. (2010). Özürlülerin sosyal dışlanma boyutları: bursa ve çanakkale örneklerinden yansıyanlar. II. Sosyal Haklar Ulusal Sempozyumu Bildiri Kitabı, Denizli, 217-243.

Peace, R. (2001). Social exclusion: a concept in need of definition, Social Policy Journal of New Zealand, No. 16, 21-36.

Poggi, A. (2007). Does persistence of social exclusion exist in Spain?, Springer Science + Business Media B.V., 53-72

Şenol, E., (2010), İşsizliğin sosyal dışlanma üzerindeki etkileri, Gazi Üniversitesi Sosyal Bilimler Enstitüsü Çalışma Ekonomisi ve Endüstri İlişkileri Anabilim Dalı, Doktora Tezi, Ankara.

Timurçin, D. (2010). Türkiye'de Kobi’lerin rekabet gücü ve rekabet üstünlüğü sağlamada kümelenmenin etkisi. Yayımlanmamış Doktora Tezi, İstanbul Üniversitesi Sosyal Bilimler Enstitüsü, İstanbul.

Tsakloglou, P., Papadopoulos, F. (2002). Poverty, Material Deprivation And Multi-Dimensional Disadvantage During Four Life Stage: Evidence From ECHP. In: Heady, C. (ed.) Poverty and social exclusion in Europe. E. Elgar, Cheltenham; Northampton, MA.

Wagle, U. (2002). Rethinking poverty: definition and measurement, International Social Science Journal, Volume:54, Issue: 171, March, 155-165.

Yeldan, E. (2008). Küreselleşme sürecinde Türkiye ekonomisi. İletişim Yayınlarl, 13. Baskı, İstanbul. 
Selim, S., Çomuk, P., (2017). Yoksunluk yaşayan bireyler sosyal dışlanmaya maruz kalır mı? Türkiye örneği. International Journal of Social Sciences and Education Research, 3 (3), 1041-1053.

\section{Extended abstract in English}

Social exclusion is the fact that social groups and individuals must not be able to make full use of social relations and life, or even social participation, even if they are physically within the community (Çakir, 2002: 83). The economic, social and political deprivations that individuals have experienced cause individuals to push themselves out of society, or individuals to remove themselves from society, and to live in social exclusion.

The concept "social exclusion" emerged in France in the 1970s and it has quickly been recognized as a concept in other European countries and has spread rapidly. Because of increasing international migrations and the rate of unemployment and the decline in the welfare state, the importance of the concept "social exclusion" has gradually increased. The concept "social exclusion" has been accepted as a problem in the developing and the developed countries and countries has started to include social exclusion into their social policies. In this context, the aim of this study is to generate deprivation index by considering important elements finding out social exclusion using Income and Living Conditions (Panel) Research Data produced by Turkish Statistical Institute in the periods of 2010-2013 and is to examine with panel regression model the factors giving rise to social exclusion with which individuals lacking education, health and housing opportunities. Indicators that are used in obtaining deprivation numbers are obtained economic exclusion, exclusion from the social support and exclusion of deprivation of qualification results. The deprivation index will be formed by normalizing the basic components, with the mean and standard deviations of each variable. Dependent variables for this study is the deprivation index. Independent variables are age, gender, education status, type of property ownership, health status of individual, occupational group and marital status.

In this study, panel data analysis models will be used. Panel data models have significant advantages according to time series and / or cross-section models. In these models, the number of observations will be more than the cross-sectional and time series, so that the parameter estimates to be obtained will become more reliable. Moreover, the predicted models will be based on less restrictive assumptions. Panel data models allow the establishment and testing of more complex behavioral models than other methods. Panel data analysis allows for the establishment of a dynamic model since it has time dimension.

When the studies on the concept of social exclusion are examined, it is seen that the theoretical studies are in general and the relation with the limited number of poverty is examined. An econometric study of social exclusion has not been found in the literature by obtaining the number of deprivations of individuals and by creating the deprivation index.

According to the findings obtained from the study, it was seen that the individuals in Turkey had a significant effect on the deprivation of variables such as gender, age, education, ownership style, general health status, marital status and occupation group variables. Öztürk and Çetin (2009) point out that women and children are excluded due to more deprivation than men in their study, whereas in this study men were more exposed to social exclusion than women. When educational level is examined, social exclusion decreases as education level increases. Those who own property-type housing are fewer than those who own it, and those who are tenants and those who live in other dwellings live and are more deprived than those who are homeowners. As the general health status of individual deteriorates, the social exclusion situation also increases. When we look at the individual marital status, the bachelors have been subjected to social exclusion 
Selim, S., Çomuk, P., (2017). Yoksunluk yaşayan bireyler sosyal dışlanmaya maruz kalır mı? Türkiye örneği. International Journal of Social Sciences and Education Research, 3 (3), 1041-1053.

largely according to the others. According individuals who exposed to social exclusion faced with social exclusion in the later part of lives of them.

As a result, as the Hekimler (2012) pointed out, developments all over the world indicate that social exclusion is a multidimensional deprivation process, in which case political, social and cultural elements must also be included in this process. Individuals who are deprived of social, economic and competence are exposed to social exclusion and adversely affect their lives. In order to reduce the deprivation of the individual and prevent their social exclusion, it is necessary to make important decisions about social exclusion while determining the social policies of the countries. 